\title{
Penentuan Massa Jenis Oli Secara Sederhana dengan Hukum Archimedes
}

\author{
S. Gideon* dan E. R. Tarigan \\ Politeknik Teknologi Kimia Industri Medan, Indonesia \\ * email: mysuperemail1988@gmail.com
}

Received: November 215t, 2019. Accepted: February $2^{\text {nd }}, 2020$. Published: February $29^{\text {th }}, 2020$

\begin{abstract}
Abstrak
Metode pengukuran massa jenis zat cair yang paling umum digunakan adalah berdasarkan hukum Archimedes. Minyak pelumas (oli) umumnya telah mempunyai standar massa jenis yang telah ditetapkan untuk menunjukkan kualitas dari oli tersebut. Tujuan dari penelitian ini adalah menentukan massa jenis oli secara sederhana dengan menerapkan hukum Archimedes. Penelitian ini dilakukan dalam tiga tahap. Pertama, pengukuran massa piknometer kosong. Ke dua, pengukuran massa piknometer berisi air suling dan oli. Ke tiga, pengukuran massa tembaga di medium udara, air suling dan oli. Hasil pengukuran dan perhitungan menunjukkan massa jenis air suling sebesar $\left(0,995 \pm 3,582 \times 10^{-4}\right) \mathrm{gr} / \mathrm{cm}^{3}$ yang nilainya sangat dekat dengan nilai $1 \mathrm{gr} / \mathrm{cm}^{3}$ sehingga air suling yang digunakan dalam penelitian ini cocok sebagai referensi/standar dalam mencari volume tembaga; massa jenis oli sebesar $(0,868 \pm 2,14 \mathrm{x}$ $\left.10^{-3}\right) \mathrm{gr} / \mathrm{cm}^{3}$ yang nilainya sangat dekat dengan nilai massa jenis oli yang diukur dan dihitung dengan piknometer sebesar $(0,875$ $\left.\pm 4,637 \times 10^{-4}\right) \mathrm{gr} / \mathrm{cm}^{3}$.
\end{abstract}

\begin{abstract}
The most commonly used method for measuring the density of liquids is based on Archimedes' law. Lubricating oil generally has a defined density standard to show the quality of the oil. The purpose of this study is to determine oil density simply by applying Archimedes' law. This research was conducted in three steps. First, the measurement of the empty pycnometer. Second, the measurement of the pycnometer mass containing distilled water and oil. Third, measurement of copper mass in the medium of air, distilled water and oil. From the results of
\end{abstract}


measurements and calculations, the obtained density of distilled water is $\left(0.995 \pm 3,582 \times 10^{-4}\right) \mathrm{gr} / \mathrm{cm} 3$ whose value is very close to the value of $1 \mathrm{gr} / \mathrm{cm}^{3}$ so that the distilled water used in this study is suitable as a reference/standard in finding volume copper; oil density is $\left(0.868 \pm 2.14 \times 10^{-3}\right) \mathrm{gr} / \mathrm{cm}^{3}$ whose value is very close to the value of oil density measured and calculated with a pycnometer of $\left(0.875 \pm 4.637 \times 10^{-4}\right) \mathrm{gr} / \mathrm{cm}^{3}$. (C2020PERJ

Keywords: Archimedes' principle; oil density; pycnometer.

\section{PENDAHULUAN}

Materi atau zat dapat berwujud padat, cair atau gas. Cairan dan gas tidak dapat mempertahankan bentuk yang tetap dan memiliki kemampuan yang mengalir sehingga keduanya secara kolektif disebut fluida (Giancoli, 2014). Salah satu besaran karakteristik (sifat) dari fluida adalah densitas/kerapatan atau yang biasa disebut massa jenis. Benda-benda yang terbuat dari zat tertentu, dapat memiliki sembarang ukuran atau massa, namun massa jenisnya akan selalu sama (Serway dan Jewett, 2014).

Metode pengukuran massa jenis zat cair yang paling umum digunakan adalah berdasarkan hukum Archimedes. Hukum Archimedes menjelaskan bahwa gaya apung pada benda yang dicelupkan ke dalam fluida adalah sama dengan berat fluida yang dipindahkan oleh benda tersebut (Bierman dan Kincanon, 2003; Mccuan dan Treinen, 2009; Hughes 2005; Hughes, 2006).

Secara eksperimen, hukum Archimedes yang digunakan untuk mendapatkan massa jenis air suling dan oli dapat dituliskan sesuai Persamaan 1 (Kireš, 2007).

$$
F_{A}=\left(m_{u}-m_{f}\right) \cdot g
$$

dengan $F_{A}$ adalah gaya angkat benda yang dicelupkan dalam suatu fluida (satuan Newton), $m_{u}$ adalah massa benda ketika ditimbang di udara (satuan gram), $m_{f}$ adalah massa benda ketika ditimbang di dalam suatu fluida (satuan gram) dan $g$ adalah percepatan gravitasi (satuan meter per sekon kuadrat).

Persamaan 1, dapat diubah dalam bentuk Persamaan 2 (Loverude, Kautz, dan Heron, 2003).

$$
V_{B}=\frac{F_{A}}{\rho_{f} \cdot g}
$$

dengan $V_{B}$ adalah volume benda yang dicelupkan dalam suatu fluida (satuan meter kubik), $F_{A}$ adalah gaya angkat benda yang dicelupkan dalam suatu fluida (satuan Newton), $\rho_{f}$ adalah massa jenis benda yang dicelupkan di dalam suatu fluida (satuan kilogram per meter kubik) dan $g$ adalah percepatan gravitasi (satuan meter per sekon kuadrat). 
Aplikasi dari hukum Archimedes tersebut melatarbelakangi munculnya berbagai jenis peralatan praktikum hukum Archimedes dalam mengukur massa jenis suatu zat cair. Peralatan praktikum tersebut antara lain piknometer, aerometer, hidrometer dan neraca Mohr. Putra dan Purnomosari (2015) mengembangkan modul praktikum hukum Archimedes untuk menentukan massa jenis air murni, larutan garam, dan alkohol menggunakan aerometer, neraca Mohr; sedangkan Masthura, Jumiati, dan Sirait (2017) mengembangkan modul praktikum hukum Archimedes untuk menentukan massa jenis air murni dan larutan garam menggunakan hidrometer.

Selain modul-modul praktikum hukum Archimedes yang telah dikembangkan tersebut, terdapat beberapa penelitian yang menggunakan hukum Archimedes untuk menentukan massa jenis. Putra (2014) merancang dan menerapkan neraca digital untuk percobaan menentukan massa jenis zat padat. Prawira dan Rouf (2018) merancang alat ukur massa jenis zat cair menggunakan cepat rambat gelombang ultrasonik. Pande (2017) merancang alat ukur massa jenis zat cair berdasarkan tekanan hidrostatik dengan menggunakan sensor fotodioda. Kartika (2009) merancang alat ukur massa jenis zat cair dengan menggunakan metode Mohr. Nurlaili dan Haiyum (2008) melakukan penelitian untuk menentukan massa jenis air dan minyak tanah dengan menggunakan hukum Archimedes. Penelitian tersebut menggunakan sebuah tabung yang dimasukkan ke dalam sebuah bejana yang berisi air, sehingga sebagian dari tabung tercelup ke dalam air dan sebagian lagi muncul di udara.

Zat cair yang biasa diukur massa jenisnya yaitu produk susu, minyak goreng atau minyak pelumas (oli). Susu, minyak goreng, dan oli umumnya telah mempunyai standar massa jenis yang telah ditetapkan untuk menunjukkan kualitas dari zat cair tersebut (Sutiah, Firdausi, dan Budi, 2008). Terkait dengan hal tersebut dan seluruh pemaparan yang telah dijelaskan, maka penelitian ini dilakukan dengan tujuan untuk menentukan massa jenis oli secara sederhana dengan menerapkan hukum Archimedes.

\section{METODE}

Alat dan bahan yang digunakan dalam penelitian ini adalah piknometer $10 \mathrm{~mL}$ seperti terlihat pada Gambar 1, neraca Ohaus digital, neraca pegas digital, statif, beaker glass, air suling dan batu logam dengan bentuk tidak 
beraturan terbuat dari bahan tembaga).

Piknometer digunakan karena merupakan salah satu alat ukur massa jenis zat cair yang standar. Air suling dipilih sebagai fluida referensi karena massa jenisnya yang bernilai $\approx 1 \mathrm{gr} / \mathrm{cm}^{3}$. Minyak pelumas (oli) yang digunakan adalah oli mesin motor merk Ultratec jenis 20W-50 JASO MA. Skema rangkaian pengukuran ditunjukkan pada Gambar 2.

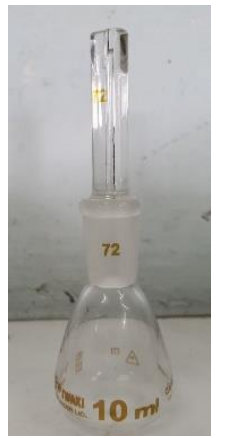

Gambar 1. Piknometer $10 \mathrm{~mL}$

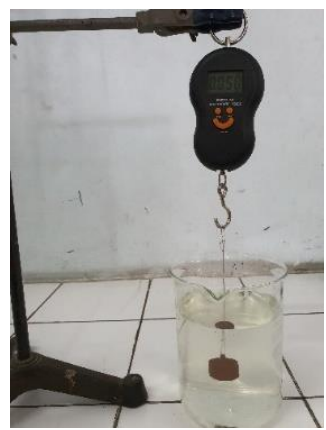

Gambar 2. Skema Rangkaian Pengukuran

Penelitian ini dilakukan dalam tiga tahap. Pertama, massa piknometer kosong diukur dengan neraca Ohaus digital sebanyak tiga kali. Ke dua, air suling dan oli masing-masing dimasukkan ke dalam piknometer kemudian massanya diukur sebanyak tiga kali. Ke tiga, beberapa batu logam (bahan aluminium, besi, dan tembaga) masing-masing diukur massanya sebanyak tiga kali, baik di medium udara maupun di medium air suling dan oli (dengan cara dicelupkan).

\section{HASIL DAN PEMBAHASAN}

Hasil pengukuran massa piknometer kosong, piknometer berisi air suling dan piknometer berisi oli disajikan pada Tabel 1 . Berdasarkan Tabel 1, secara perhitungan statistik didapatkan massa piknometer kosong sebesar $\left(15,7 \pm 1,8 \times 10^{-2}\right)$ gr, massa piknometer berisi air suling sebesar $\left(15,7 \pm 1,8 \times 10^{-2}\right)$ gr dan massa piknometer berisi oli sebesar $(15,7 \pm$ $\left.1,8 \times 10^{-2}\right)$ gr. Massa jenis air suling dan oli ditentukan dengan menggunakan Persamaan 3.

$$
\rho_{f}=\frac{\left(m_{p k o}-m_{p b f}\right)}{V_{P}}
$$

dengan $\rho_{f}$ adalah massa jenis fluida yang dimasukkan ke dalam piknometer (satuan gram per centimeter kubik), $m_{p k o}$ adalah massa piknometer kosong (satuan gram), $m_{p b f}$ adalah massa piknometer berisi fluida (satuan gram) dan $V_{P}$ adalah 
volume piknometer yang digunakan (yaitu sebesar $10 \mathrm{~mL}$ ). Berdasarkan Persamaan 3 dan perhitungan statistik diperoleh massa jenis air suling sebesar $(0,995$ $\left.\pm 3,582 \times 10^{-4}\right) \mathrm{gr} / \mathrm{cm}^{3}$ dan massa jenis oli sebesar $\left(0,875 \pm 4,637 \times 10^{-4}\right)$ $\mathrm{gr} / \mathrm{cm}^{3}$. Massa jenis air yang diperoleh nilainya sangat dekat dengan nilai $1 \mathrm{gr} / \mathrm{cm}^{3}$. Oleh karena itu, air suling yang digunakan dalam penelitian ini cocok sebagai nilai referensi/standar dalam mencari volume tembaga di medium air suling. Massa jenis oli yang diperoleh selanjutnya dijadikan nilai referensi massa jenis oli dalam penelitian ini.

Tabel 1. Hasil Pengukuran Massa Piknometer Kosong, Piknometer Berisi Air Suling, dan Piknometer Berisi Oli.

\begin{tabular}{cccc}
\hline Pengukuran & $\begin{array}{c}\text { Massa Piknometer } \\
\text { Kosong }(\mathrm{gr})\end{array}$ & $\begin{array}{c}\text { Massa Piknometer } \\
\text { Berisi Air }(\mathrm{gr})\end{array}$ & $\begin{array}{c}\text { Massa Piknometer } \\
\text { Berisi Oli (gr) }\end{array}$ \\
\hline Pertama & 15,72 & 25,64 & 24,46 \\
Ke dua & 15,74 & 25,66 & 24,44 \\
Ke tiga & 15,72 & 25,66 & 24,45 \\
\hline
\end{tabular}

Tabel 2 menunjukkan hasil pengukuran massa tembaga di medium udara, air suling dan oli. Berdasarkan Tabel 2 dan perhitungan statistik, didapatkan massa tembaga di medium udara sebesar $\left(62,2 \pm 13,4 \times 10^{-2}\right)$ gr, massa tembaga di medium air suling sebesar $\left(55,08 \pm 4,23 \times 10^{-2}\right)$ gr dan massa tembaga di medium oli sebesar $\left(55,95 \pm 9,19 \times 10^{-2}\right)$ gr. Selanjutnya, dengan menggunakan Persamaan 1 dan 2 maka didapatkan volume tembaga di medium air suling sebesar $(7,2 \pm$ $\left.10,31 \times 10^{-3}\right) \mathrm{cm}^{3}$.

Tabel 2. Hasil Pengukuran Massa Tembaga di Medium Udara, Air Suling, dan Oli.

\begin{tabular}{cccc}
\hline Pengukuran & $\begin{array}{c}\text { Massa Tembaga di } \\
\text { Medium Udara } \\
(\mathrm{gr})\end{array}$ & $\begin{array}{c}\text { Massa Tembaga di } \\
\text { Medium Air Suling } \\
(\mathrm{gr})\end{array}$ & $\begin{array}{c}\text { Massa Tembaga di } \\
\text { Medium Oli (gr) }\end{array}$ \\
\hline Pertama & 62,25 & 55,07 & 55,95 \\
Ke dua & 62,10 & 55,06 & 55,96 \\
Ke tiga & 62,11 & 55,11 & 55,95 \\
\hline
\end{tabular}

Tembaga yang dicelupkan ke oli adalah tembaga yang sama dengan yang telah dicari volume di medium air suling, maka dengan menggunakan Persamaan 2 didapatkan massa jenis oli sebesar 
$\left(0,868 \pm 2,14 \times 10^{-3}\right) \mathrm{gr} / \mathrm{cm}^{3}$. Nilai massa jenis oli tersebut sangat dekat dengan nilai massa jenis oli yang diukur dan dihitung dengan piknometer sebesar $(0,875 \pm 4,637 \mathrm{x}$ $\left.10^{-4}\right) \mathrm{gr} / \mathrm{cm}^{3}$.

\section{KESIMPULAN}

Berdasarkan hasil pengukuran dan perhitungan, didapatkan massa jenis air suling sebesar $(0,995 \pm 3,582$ $\left.\times 10^{-4}\right) \mathrm{gr} / \mathrm{cm}^{3}$ yang nilainya sangat dekat dengan nilai $1 \mathrm{gr} / \mathrm{cm}^{3}$ sehingga air suling yang digunakan dalam penelitian ini cocok sebagai referensi/standar dalam mencari volume tembaga; dan massa jenis oli sebesar $\left(0,868 \pm 2,14 \times 10^{-3}\right) \mathrm{gr} / \mathrm{cm}^{3}$ yang nilainya sangat dekat dengan nilai massa jenis oli yang diukur dan dihitung dengan piknometer sebesar $\left(0,875 \pm 4,637 \times 10^{-4}\right) \mathrm{gr} / \mathrm{cm}^{3}$.

\section{UCAPAN TERIMA KASIH}

Penulis mengucapkan terima kasih kepada Ibu Dr. Evi Christiani Sitepu, M.Si selaku Kepala Laboratorium Fisika PTKI Medan atas kesediaannya memberikan arahan dan kesempatan yang seluas-luasnya dalam mengeksplorasi laboratorium Fisika termasuk di antaranya dalam menyelesaikan penelitian ini. Penulis juga mengucapkan terima kasih kepada para asisten Laboratorium Fisika PTKI Medan
(Pak Maruli, Leo, Harris, Yosep dan Tommy) yang banyak membantu penulis dalam mengambil data penelitian.

\section{DAFTAR PUSTAKA}

Bierman, J. dan Kincanon, E. 2003. Reconsidering Archimedes' Principle. The Physics Teacher, 41 (6): 340-344.

Giancoli, D. C. 2014. Fisika: Prinsip dan Aplikasi Jilid 1 (I. Hardiansyah, ed.). Jakarta: Penerbit Erlangga.

Hughes, S. W. 2005. Archimedes revisited: A faster, better, cheaper method of accurately measuring the volume of small objects. Physics Education, 40 (5): 468474.

Hughes, S. W. 2006. Measuring liquid density using Archimedes' principle. Physics Education, 41 (5): 445447.

Kartika, E. 2009. Alat Ukur Massa Jenis Zat Cair Dengan Menggunakan Metode Mohr. Universitas Indonesia.

Kireš, M. 2007. Archimedes' principle in action. Physics Education, 42 (5): 484-487.

Loverude, M. E., Kautz, C. H., dan Heron, P. R. L. 2003. Helping students develop an understanding of Archimedes' principle. I. 
Research on student understanding. American Journal of Physics, 71 (11): 1178-1187.

Masthura, Jumiati, E., dan Sirait, R. 2017. Buku Panduan Praktikum: Fisika Dasar I. Medan: Universitas Islam Negeri Sumatera Utara.

Mccuan, J. dan Treinen, R. 2009. Capillarity and Archimedes' Principle of Floatation. 1-25. Retrieved from https:/ / pdfs.semanticschola r.org/215f/88954ba266efb84 8f859f23863dbbe1982fc.pdf

Nurlaili dan Haiyum, M. 2008. Mengukur Massa Jenis Minyak Tanah Dengan Menggunakan Hukum Archimedes. Prosiding Seminar Nasional Yusuf Benseh 2012, pp. 331-336.

Pande, A. 2017. Realisasi Alat Ukur Massa Jenis Zat Cair Berdasarkan Metode Tekanan Hidrostatik Dengan Menggunakan Ssnsor Fotodioda Berbasis Mikrokontroler ATMEGA 8535. Universitas Lampung. Prawira, N. B. dan Rouf, A. 2018. Perancangan Alat Ukur Massa Jenis Zat Cair Menggunakan Cepat Rambat Gelombang Ultrasonik. IJEIS (Indonesian Journal of Electronics and
Instrumentation Systems), 8 (2): 143-154.

Putra, I. G. 2014. Perancangan dan Penerapan Neraca Digital untuk Percobaan Menentukan Massa Jenis Zat Padat. Inovasi Fisika Indonesia, 3 (03): 16-20.

Putra, V. G. V. dan Purnomosari, E. 2015. Pengantar Eksperimen Fisika. Bandung: CV Mulia Jaya Publisher.

Serway, R. A. dan Jewett, J. W. 2014. Fisika untuk Sains dan Teknik Jilid 1 (C. Sungkono, Ed.). Jakarta: Penerbit Salemba Teknika.

Sutiah, Firdausi, K. S., dan Budi, W. S. 2008. Studi Kualitas Minyak Goreng Parameter Viskositas Dan Indeks Bias. Berkala Fisika, 11 (2): 53-58. 
Phy. Educ. Res. J. Vol. 2 No. 1 (2020), 43-50 